\title{
Terrestrial birds living on marine environments: does dietary composition of Cinclodes nigrofumosus (Passeriformes: Furnariidae) predict their osmotic load?
}

\author{
Aves terrestres viviendo en ambientes marinos: ¿es la composición dietaria de \\ Cinclodes nigrofumosus (Passeriformes: Furnariidae) un buen predictor de su carga \\ osmótica?
}

PABLO SABAT ${ }^{1,3 *}$, JOSÉ M. FARIÑA ${ }^{2,3}$ \& MAURICIO SOTO-GAMBOA ${ }^{3}$

${ }^{1}$ Departamento de Ciencias Ecológicas, Facultad de Ciencias, Universidad de Chile, Casilla 653, Santiago, Chile; e-mail: psabat@uchile.cl

${ }^{2}$ Ecology and Evolutionary Biology Department, Brown University, Box GW, 80 Waterman Street, Providence, Rhode Island 02912, USA

${ }^{3}$ Center for Advanced Studies in Ecology and Biodiversity (CASEB), Pontificia Universidad Católica de Chile, Casilla 114-D, Santiago

(*corresponding author), Chile.

\begin{abstract}
Feeding on saline marine foods may be especially challenging for passerine birds that lack functional salt glands and have a limited ability to concentrate urine. To reduce the salt load imposed by consumption of marine food these birds may select food with low salt contents and/or increase their intake of freshwater. The genus Cinclodes is particular among passerines because it includes species that inhabit both inland and maritime shores. We analyzed the diet of Cinclodes nigrofumosus and explored the possible relationships between dietary composition and salt load at mesic and arid coastal sites of Chile. From a biogeographical perspective, we hypothesized that freshwater availability is critical to the relationship between diet composition and osmotic load of $C$. nigrofumosus. Our analysis of prey abundance and distribution indicated that the diet of $C$. nigrofumosus is composed mainly by marine prey, in spite of the availability of terrestrial insects at both sites. Stomach content osmolality was higher in the arid site, but it was not correlated with prey type, which suggests that Cinclodes nigrofumosus avoid a high osmotic load, drinking fresh water when available. Thus physiological constraints are modulating niche breath of Cinclodes.
\end{abstract}

Key words: Cinclodes, dietary habits, osmoregulation, osmotic load.

\section{RESUMEN}

Alimentarse de presas marinas representa un desafío para aves paseriformes que no poseen glándula de la sal y tienen una habilidad limitada para concentrar orina. Para reducir la carga osmótica asociada al consumo de presas marinas estas aves podrían optar por incluir presas con bajas concentraciones salinas en su dieta y/o aumentar la ingestión de agua dulce. El género Cinclodes es particular entre los paseriformes debido a que incluye especies que habitan riberas de lagos, ríos y costas marinas. Analizamos la dieta de Cinclodes nigrofumosus y exploramos la posible relación entre la composición de ésta y la carga salina en dos sitios costeros de Chile, uno mésico y otro árido. En este estudio planteamos que desde una perspectiva biogeográfica, la disponibilidad de agua dulce es un factor que determina la relación entre la composición dietaria y la carga osmótica de esta especie. Nuestro análisis de abundancia y distribución de presas indicó que la dieta de C. nigrofumosus está compuesta principalmente por presas marinas independiente de la disponibilidad de insectos terrestres en ambos sitios. La osmolalidad del contenido estomacal fue mayor en el sitio árido, pero no se correlacionó con el tipo de presas consumidas, sugiriendo que Cinclodes evita una alta carga osmótica a través de ingerir agua dulce cuando está disponible. Estos resultados apoyan que una restricción fisiológica sería el factor que modula la amplitud de nicho en Cinclodes.

Palabras clave: Cinclodes, hábitos alimentarios, osmoregulación, carga osmótica.

\section{INTRODUCTION}

For most birds and other air-breathing vertebrates marine environments are osmotically stressful. This is so because birds generally have only saline water to drink and available prey (specially invertebrates) are in osmotic equilibrium with the environment, imposing a salt load for consumers (Johnston \& Bildstein 1990, Janes 1997). Physiological stress associated with life in marine and other saline habitats does not result from the absence of water, but from the necessity of elimi- 
nating excess electrolytes. Concentration of salts (e.g., $\mathrm{K}^{+}, \mathrm{Cl}^{-}, \mathrm{Na}^{+}, \mathrm{SO}_{4}^{-2}$ ) is always high in the marine environment. Seawater has sodium and chloride concentrations of approximately 470 and $548 \mathrm{mM}$, respectively, whereas these salts are at concentrations of $7 \mathrm{mM}$ and $14 \mathrm{mM}$ in freshwater habitats (Schmidt-Nielsen 1997). When birds drink seawater or consume food with high osmolality, salts are absorbed by the small intestine, and their concentration in the body fluids increase (Purdue \& Haines 1977, Simon 1982, Holmes \& Phillips 1985). Body would become dehydrated unless birds can excrete fluids more concentrated than the ingested water. Hence, osmotic load imposed by the consumption of osmoconformist prey (e.g., prey with a salt concentration similar to that of their surrounding environment), is probably the main physiological factor limiting consumption of marine prey by terrestrial consumers.

Unlike mammalian kidneys that can produce highly concentrated urine, avian kidneys have a poor concentrating ability (Dantzler \& Braun 1980, Braun 1981, Goldstein \& Braun 1989). Some birds are able to cope with salt water using an extrarenal excretory system: the supraorbital or nasal gland. This gland excretes concentrated electrolyte solutions (Holmes \& Phillips 1985) allowing marine birds to maintain a positive water balance while drinking hypertonic solutions and while ingesting hypertonic prey, without having to consume freshwater. Nasal glands are very efficient for salt excretion. For example, the gull Larus argentatus can secrete solutions containing $800 \mathrm{mmol} \mathrm{L}^{-1}$ of sodium and those of the petrel Oceanodroma leucorhoa can concentrate above $1100 \mathrm{mmol} \mathrm{L}^{-1}$ (Schmidt-Nielsen 1997). Considering that normal sodium concentration in the blood plasma of marine birds is approximately $150 \mathrm{mmol} \mathrm{L}^{-1}$, the concentrating ability of salt glands can reach from five to eight times.

Feeding on saline marine foods may be especially challenging for Passerine birds because they lack functional salt glands (Shoemaker 1972) and have a limited ability to concentrate urine (Goldstein \& Skadhauge 2000). In this situation, salt stress may be avoided or minimized by feeding in habitats of low salinity, by drinking fresh water, by feeding on less saline food, and/or through increasing kidney volume and efficiency (Mahoney \& Jehl 1985, Nyström \& Pehrsson 1988). For example, savannah sparrows (Passerculus sandwichenis), living in salt marshes with little fresh water, can tolerate this dry and saline environment by feeding on terrestrial plants, seeds, and on terrestrial insects (Poulson \& Bartholomew 1962, Goldstein et al. 1990).
The genus Cinclodes (Passeriformes: Furnariidae) is unique among passerine birds because it includes species that live exclusively at intertidal zones (Goodall et al. 1946, Hockey et al. 1987), and species that also inhabit inland terrestrial environments (Housse 1945, Goodall et al 1946). Cinclodes nigrofumosus (d'Orbigny \& Lasfrenaye, Seaside Cinclodes) inhabits intertidal zones and feeds almost exclusively on marine invertebrates (Goodall et al. 1946, Paynter 1971, Hockey et al. 1987). The feeding ecology of Cinclodes species is scarcely known. According to preliminary reports, some species are carnivorous and have a diet based mostly on aquatic invertebrates including marine crustaceans and mollusks (Paynter 1971, Hockey et al. 1987).

In Chile several species of Cinclodes are conspicuous components of marine coastal and river bird assemblages. The latitudinal distribution of these species ranges from the dry Atacama Desert region in the north $\left(18^{\circ} \mathrm{S}\right)$, to the cold-wet fjord region $\left(47^{\circ} \mathrm{S}\right)$ in the south (Araya et al. 1986). Within this geographical range, rainfall varies from less than $40 \mathrm{~mm}$ year $^{-1}$ in the north to almost 3,000 $\mathrm{mm}^{\text {year }}{ }^{-1}$ in the south (di Castri \& Hayek 1976). Given this gradient in rainfall, birds living on the northern regions face a very different challenge as compared with birds living in central and southern areas. Freshwater in northern Chile is scarce, and since terrestrial productivity is related to rainfall (Lieth 1978), low levels of terrestrial prey are probably available for these birds.

The objective of this study was to determine the diet and osmotic load of Cinclodes nigrofumosus, and analyze the influence of these variables on both prey and freshwater availability of coastal northern and central Chile. From a biogeographical perspective, we hypothesized that in the northern areas of Chile (where there is no freshwater) birds must have a higher osmotic load, and they must ingest more terrestrial prey on their diet when available to reduce stomach osmolality.

\section{MATERIAL AND METHODS}

\section{Study sites}

The geographical distribution of C. nigrofumosus ranges from Arica $\left(18^{\circ} \mathrm{S}\right)$ to Valdivia $\left(39^{\circ} \mathrm{S}\right)$ (Araya et al. 1986, Fig. 1). The study was conducted at two coastal sites of Chile: Taltal on the northern Atacama Desert (25⒉ ' S, 70³4' W, Fig. 1) and El Quisco, on the central temperate region ( $\left.33^{\circ} 34^{\prime} \mathrm{S}, 71^{\circ} 37^{\prime} \mathrm{W}\right)$. Climatically, Taltal is located in an arid-desert region (mean precipitation $25.1 \mathrm{~mm}$ year $^{-1}$ ), whereas El Quisco 
is located on a mesic-temperate region (mean precipitation $441.3 \mathrm{~mm}$ year ${ }^{-1}$, di Castri \& Hajek 1976).

\section{Diet and osmotic load}

In order to study bird diet and osmotic load, 16 individuals of $C$. nigrofumosus were collected while they were feeding on the intertidal rocky shores of both sites either by the use of mist nets or shot. Collection was done during summer season (December to February). After capture birds were weighed $( \pm 0.05 \mathrm{~g})$ and their stomachs (proventriculus and gizzard) immediately remo-

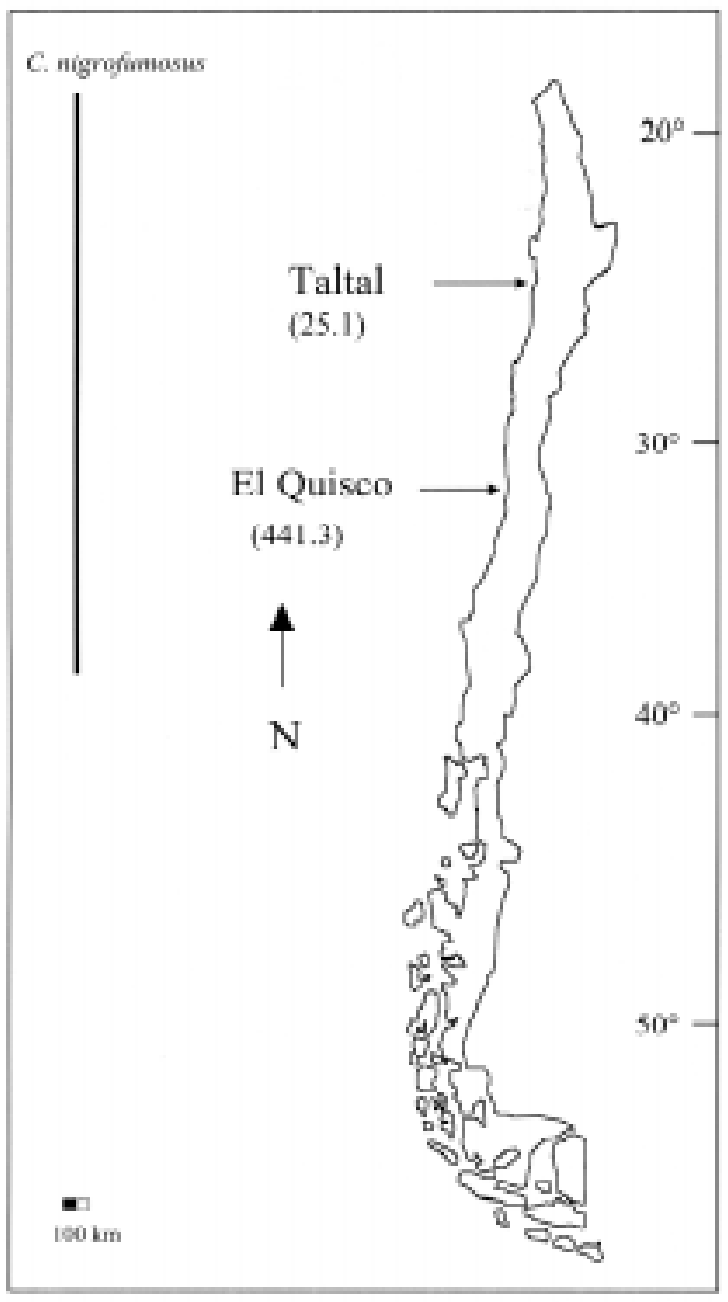

Fig. 1: Location of the two study sites, their average annual rainfall $\left(\mathrm{mm}\right.$ year $\left.^{-1}\right)$ and the geographical distribution of $C$. nigrofumosus along the Chilean coast.

Ubicación de ambos sitios de estudio, precipitación promedio anual $\left(\mathrm{mm} \mathrm{año}^{-1}\right)$ y la distribución geográfica de C. nigrofumosus a lo largo de la costa chilena. ved. Stomachs were manually compressed and the fluids collected in an eppendorf tube and frozen in liquid nitrogen. In the laboratory, fluids were centrifuged $(12.000 \mathrm{G}, 5 \mathrm{~min})$ and the osmolality of the supernatant was determined by vapor pressure osmometry (Wescor 5130B). Stomach contents were thawed and then deposited in a petri dish for further analysis. Prey items were separated, weighed $( \pm 0.0005)$ and identified to the lowest possible taxonomic level.

Dietary composition was determined using the frequency of occurrence of each dietary item in the guts (FO) measured as the number of birds where the item was observed, and percentage of weight of that item on the total gut content (\%). Stomach osmotic load of individuals captured were compared using one-way analysis of variance (ANOVA). Site was considered as the main factor with two levels. Normality, homogeneity of variances and independence of the data were verified using Shapiro-Wilk test (W), Levene's and Durbing-Watson tests, respectively (Wilkinson et al. 1996).

Dietary composition of the individuals captured at both sites were compared using the nonparametric Kendall test of concordance (Siegel \& Castellan 1988) on the calculated weight percentage of the dietary items (\%). The test considers a null hypothesis of no-association for ranked variables. After the analysis, dietary items were pooled into three main categories: Crustacea, Mollusca and Insecta. The relative contribution of those categories to diet composition at each site was compared using one-way ANOVA. Normality, homogeneity of variances and independence of the data were checked as explained above and standard procedures of data transformations (i.e., $\operatorname{arc}-\sin \mathrm{x})$ were used. The results are reported using the original, untransformed data. Pearson correlation tests were used to analyze the possible relationships between the number of prey items under each category, their contribution to diet (\% weight), and the osmotic load of each bird.

\section{Availability of prey}

We analyzed patterns of diversity and abundance of mobile organisms in the rocky intertidal zone at each site. To do this, during low tides, a series of 10 plots of $0.25 \times 0.25 \mathrm{~m}$ were randomly placed parallel to the shoreline, between high and low intertidal levels. The high intertidal level was determined from the distance between water level during low tide conditions and the zone where the surface stand dry under all tides conditions and 
receives water only during the most high tides of the year. The low intertidal level was determined considering the distance between water level during low tide conditions and the belt of intertidal kelps Lessonia nigrescens that was present in both study sites. Mid intertidal level was established as the mid distance between low and high intertidal levels. Intertidal levels were determined a priori using the high and low water marks predicted by tide tables, during days of similar tidal and sea conditions (Castilla 1988). Small mobile species (i.e., less than $5 \mathrm{~cm}$ in body length) occurring under each plot were identified to the lowest possible taxonomic level and counted. Abundance and diversity of mid-sized (i.e., between 5 to $20 \mathrm{~cm}$ in body length) mobile organisms were recorded during visual transects on the intertidal areas. In each transect, $100 \mathrm{~m}$ of coastline were walked and individuals of each species in the intertidal areas were recorded. Additionally, we estimated the abundance of highly mobile-small organisms (i.e., Dipterous and Amphipods) by means of using tiding glue traps (Abepco, Orange, California) attached to rocky surfaces for $2 \mathrm{~h}$. Each trap is a piece of cardboard with an $8.5 \times 12.0 \mathrm{~cm}$ glued area. Trapped insects and invertebrates were counted and identified to the lowest possible taxonomic unit. Abundances of captured organisms were compared using two-way analysis of variance (ANOVA), considering sites and intertidal levels as random factors with two and three levels, respectively. Species composition of small and mid sized species occurring on the intertidal areas of each site were compared using a non-parametric Kendall test of concordance (Siegel \& Castellan 1988). This test considers the null hypothesis of no-association between ranked variables (species composition of each site).

\section{RESULTS}

\section{Composition of diet}

A total of 12 different prey items were recognized in the digestive tracts (Table 1). There was no significant association between dietary composition of individuals at each site (Kendall coefficient of concordance $=0.0025, \chi_{2,12}^{2}=0.036, \mathrm{P}=$ 0.9012).

At El Quisco (mesic site) Allopetrolisthes sp., Crustacean remains and Amphipoda-Gamaridae showed the highest occurrences (with 6, 4 and 3 of FO, respectively), while in terms of percentage of weight, Allopetrolisthes sp. and crustacean remains had the highest scores (with 33.64 and $41.90 \%$, respectively). In Taltal (arid site)

TABLE 1

Dietary Composition of $C$. nigrofumosus in the study sites: $(\mathrm{FO})=$ frequency of occurrence (number of individuals in which the dietary item was observed); $(\%)=$ item percentage of weight on the total gut content; $(\mathrm{n})=$ number of stomachs analyzed

Composición dietaria de C. nigrofumosus en los sitios de estudio: $(\mathrm{FO})=$ frecuencia de ocurrencia (numero de individuos en los cuales el ítem dietario fue observado); $(\%)=$ porcentaje del ítem en peso del total del contenido estomacal; $(\mathrm{n})$ = número de estómagos examinados

\begin{tabular}{|c|c|c|c|c|}
\hline \multirow[t]{3}{*}{ Dietary item } & \multicolumn{4}{|c|}{ Site } \\
\hline & \multicolumn{2}{|c|}{ El Quisco $(n=7)$} & \multicolumn{2}{|c|}{ Taltal $(\mathrm{n}=8)$} \\
\hline & $\mathrm{FO}$ & $\%$ & $\mathrm{FO}$ & $\%$ \\
\hline \multicolumn{5}{|l|}{ Crustaceans } \\
\hline Amphipoda-Gamaridae & 3 & 4.16 & 6 & 2.73 \\
\hline Isopoda & 2 & 1.68 & 3 & 2.21 \\
\hline Grapsus grapsus & - & - & 2 & 14.17 \\
\hline Leptograpsus variegatus & 1 & 0.92 & 5 & 59.09 \\
\hline Allopetrolisthes sp. & 4 & 33.64 & - & - \\
\hline Crustacea remains & 6 & 41.90 & - & - \\
\hline \multicolumn{5}{|l|}{ Mollusks } \\
\hline Scurria scurra & - & - & 1 & 0.07 \\
\hline Nodilittorina peruviana & 2 & 1.30 & 5 & 11.73 \\
\hline Littorina araucana & 1 & 7.88 & - & - \\
\hline Prisogaster niger & 1 & 0.22 & - & - \\
\hline \multicolumn{5}{|l|}{ Insects } \\
\hline Diptera-Adults & 2 & 8.26 & 1 & 3.13 \\
\hline Diptera-Larvae & 1 & 0.04 & 3 & 6.87 \\
\hline
\end{tabular}


Amphipoda-Gamaridae, Nodilittorina peruviana and the crab, Leptograpsus variegatus showed the highest occurrences $(6,5$ and 5 of FO, respectively). In this site Grapsus grapsus, Leptograpsus variegatus and Nodilittorina peruviana have the highest scores on percentage of weight (59.09, 14.17 and $11.73 \%$, respectively).

In spite of the above mentioned differences, the analysis of dietary items using a higher taxonomic resolution (i.e., pooling the results within Crustaceans, Mollusks and Insects) did not show significant differences between sites (Crustaceans: $\mathrm{F}_{1,13}=0.12, \mathrm{P}>0.5$; Insects: $\mathrm{F}_{1,13}=0.78, \mathrm{P}>0.3$; Mollusks: $\mathrm{F}_{1,13}=0.14, \mathrm{P}>0.5$; Fig. 2). At this level, diet of Cinclodes in both sites was composed mainly of marine prey (crustaceans and mollusks).

\section{Osmotic load}

Stomach content osmolality was different among populations $\left(\mathrm{F}_{1,12}=4.77, \mathrm{P}<0.05 ;\right.$ Fig. 3$)$. Cinclodes nigrofumosus from Taltal had more concentrated stomach fluids than individuals from El Quisco. In Taltal, the stomach content osmolality of two individuals lightly exceeded seawater osmolality (i.e., $1,000 \mathrm{mOsm} \mathrm{kg}^{-1}$ ).

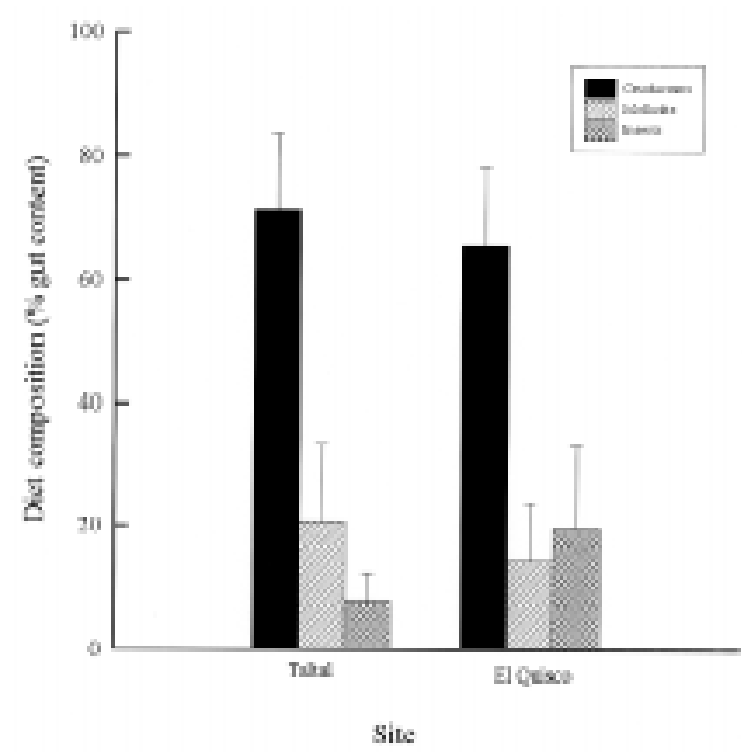

Fig. 2: Dietary composition of C. nigrofumosus estimated by the use of high taxonomic categories. Vertical lines represent $1 \mathrm{SE}$.

Composición dietaria de C. nigrofumosus estimada a partir del uso de categorías taxonómicas superiores. Las líneas verticales corresponden a $1 \mathrm{EE}$.

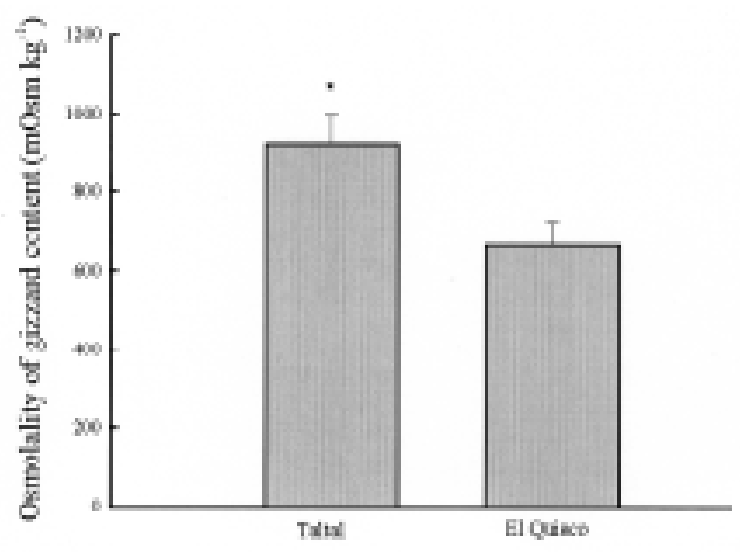

Site

Fig. 3: Stomach contents osmolality of two populations of Cinclodes nigrofumosus. Asterisk denotes statistically significant differences among populations, Tukey HSD test, $\mathrm{P}<0.05$. Vertical lines represent $1 \mathrm{SE}$.

Osmolalidad del contenido estomacal de dos poblaciones de Cinclodes nigrofumosus. El asterisco denota diferencias estadísticas significativas entre poblaciones, prueba HSD de Tukey, $\mathrm{P}<0,05$. Las líneas verticales corresponden a 1 EE.

\section{Availability of intertidal prey}

A total of 25 mobile taxa were identified in both sites (Table 2). There were significant differences in availability of mid and small sized species of Taltal and El Quisco (Kendall coefficient of concordance $\left.=0.03, \chi_{2,15}^{2}=2.12, \mathrm{P}=0.696\right)$. At El Quisco, the most abundant species in the high intertidal were the crustacean Cyclograpsus cinereus (13.4 ind $100 \mathrm{~m}^{-2}$ ) and the gastropod Scurria scurria $\left(7.2\right.$ ind $\left.0.25 \mathrm{~m}^{-2}\right)$. At this zone, Diptera adults $\left(6.26\right.$ ind $\left.0.01 \mathrm{~m}^{-2}\right)$, and Nodilittorina peruviana (3.9 ind $0.25 \mathrm{~m}^{-2}$ ) also showed high abundances. In the Mid intertidal zone, the crustaceans Petrolisthes violaceus, Allopetrolisthes punctatus and Petrolisthes granosus showed the highest abundances (10.61, 9.6 and 9.2 ind $100 \mathrm{~m}^{-2}$, respectively), while at low intertidal levels the crustaceans Acantocyclus gayi $\left(5.2\right.$ ind $\left.100 \mathrm{~m}^{-2}\right)$, Petrolisthes violaceus $(5.0$ ind $100 \mathrm{~m}^{-2}$ ) and Homalapsis plana $\left(4.4\right.$ ind $100 \mathrm{~m}^{-}$ $\left.{ }^{2}\right)$ were the most abundant species. At Taltal, the most abundant mobile organisms in the high intertidal zone were the gastropods Nodilittorina peruviana, Littorina araucana (19.3 and 19.4 ind $100 \mathrm{~m}^{-2}$, respectively), and the crustacean Amphipoda-Gamaridae $\left(5.1\right.$ ind $\left.0.25 \mathrm{~m}^{-2}\right)$. At mid intertidal zones, the crustaceans AmphipodaGamaridae (12.1 ind/0.25 $\left.\mathrm{m}^{2}\right)$, Leptograpsus 
variegatus (6.6 ind $100 \mathrm{~m}^{-2}$ ) and adults of Diptera (10.3 ind $0.01 \mathrm{~m}^{-2}$ ) were the most abundant species. In contrast, solely the gastropod Littorina araucana (39.3 ind $100 \mathrm{~m}^{-2}$ ) was the most abundant prey in the low intertidal level.

Captures on glue trap showed significant differences in the abundance of flies between sites $\left(F_{1,56}=7.548, P=0.008\right)$ and for the interaction between site and intertidal level $\left(\mathrm{F}_{1,56}=14.45 ; \mathrm{P}=\right.$ $0.0004)$. More flies were captured on Taltal than in El Quisco (7.6 and 4.3 ind $100 \mathrm{~m}^{-2}$, respectively), and the abundance at mid intertidal levels of Taltal was higher than all other site and intertidal level combinations (see Table 2).

\section{Dietary composition and osmotic load}

No significant relationship was observed between gut osmolality and the dietary composition of $C$. nigrofumosus. Neither the number of items on each dietary group $\left(r_{s}=0.14, P=0.19 ; r_{s}=0.04\right.$, $\mathrm{P}=0.53$; and $\mathrm{r}_{\mathrm{s}}=0.28, \mathrm{P}=0.60$, for the number of prey items of crustaceans, mollusks and insects, respectively) nor their relative contribution to diet composition $\left(\mathrm{r}_{\mathrm{s}}=0.02, \mathrm{P}=0.62 ; \mathrm{r}_{\mathrm{s}}=0.01, \mathrm{P}\right.$ $=0.69 ;$ and $r_{s}=0.23, P=0.17$, for the percentage of weight of crustaceans, mollusks and insects, respectively) showed any significant relation with gut osmolality.

TABLE 2

Mobile species composition and densities recorded from plots $\left({ }^{1}\right.$ mean individuals $0.25 \mathrm{~m}^{-2} \pm 1$ SD), visual transects ( ${ }^{2}$ mean individuals $\left.100 \mathrm{~m}^{-2} \pm 1 \mathrm{SD}\right)$, and glue traps ( ${ }^{3} \mathrm{mean}$ individuals $\left.0.01 \mathrm{~m}^{-2} \pm 1 \mathrm{SD}\right)$ in different intertidal levels at both study sites

Composición de especies móviles y densidades registradas de las parcelas ( ${ }^{1}$ promedio de individuos $0,25 \mathrm{~m}^{-2} \pm 1$ $\mathrm{DE})$, transectos visuales ( ${ }^{2}$ promedio de individuos $\left.100 \mathrm{~m}^{-2} \pm 1 \mathrm{DE}\right)$ y trampas de contacto $\left({ }^{3}\right.$ promedio de individuos $\left.0,01 \mathrm{~m}^{-2} \pm 1 \mathrm{DE}\right)$ en los distintos niveles del intermareal de ambos sitios de estudio

\begin{tabular}{|c|c|c|c|c|c|c|}
\hline \multirow[t]{3}{*}{ Species } & \multicolumn{6}{|c|}{ Site } \\
\hline & \multicolumn{3}{|c|}{ El Quisco } & \multicolumn{3}{|c|}{ Taltal } \\
\hline & High & Mid & Low & High & Mid & Low \\
\hline \multicolumn{7}{|l|}{ Mollusks } \\
\hline Polyplacophora ${ }^{1}$ & $0.3(1.32)$ & - & $0.5(1.3)$ & - & - & - \\
\hline Prisogaster niger ${ }^{1}$ & - & - & - & - & - & $1.8(3.9)$ \\
\hline Tegula atra ${ }^{1}$ & - & - & $0.1(0.3)$ & - & - & $0.03(0.2)$ \\
\hline Nodilittorina peruviana 1 & $3.9(6.4)$ & - & - & $19.3(32.9)$ & - & - \\
\hline Littorina araucana $^{1}$ & - & - & - & $19.4(30.0)$ & $0.03(0.2)$ & $39.3(59.2)$ \\
\hline Collisella parasitica $^{1}$ & $0.7(1.7)$ & $0.2(0.7)$ & $0.7(1.4)$ & $0.1(0.4)$ & $0.1(0.7)$ & - \\
\hline Scurria scurra 1 & $7.2(6.6)$ & $8.5(8.2)$ & $0.4(0.9)$ & - & $0.1(0.4)$ & - \\
\hline Collisella bohemita ${ }^{1}$ & - & - & $0.3(0.9)$ & $0.2(0.6)$ & $0.4(0.9)$ & - \\
\hline Fissurella crassa ${ }^{1}$ & - & - & $0.2(0.5)$ & - & - & - \\
\hline \multicolumn{7}{|l|}{ Crustacea } \\
\hline Amphipoda ${ }^{1}$ & $1.3(0.2)$ & $4.2(2.5)$ & - & $5.1(10.8)$ & $12.1(20.7)$ & - \\
\hline Acarii $^{1}$ & - & - & - & $0.2(0.6)$ & - & - \\
\hline Grapsus grapsus ${ }^{2}$ & - & - & & $1.8(0.4)$ & $5.2(0.8)$ & $1.6(0.5)$ \\
\hline Leptograpsus variegatus ${ }^{2}$ & - & $0.4(0.5)$ & $0.2(0.4)$ & $5.2(1.1)$ & $6.6(2.3)$ & $1.2(0.4)$ \\
\hline Cyclograpsus cinereus ${ }^{2}$ & $13.4(3.1)$ & $9.6(0.9)$ & $0.2(0.4)$ & - & - & - \\
\hline Homalapsis plana ${ }^{2}$ & - & $0.4(0.5)$ & $4.4(1.5)$ & - & - & - \\
\hline Acantocyclus gayi ${ }^{2}$ & - & $2.4(1.5)$ & $5.2(2.1)$ & - & - & $0.2(0.4)$ \\
\hline Paraxanthus barbiger $^{2}$ & - & $0.2(0.5)$ & $0.2(0.4)$ & - & - & - \\
\hline Allopetrolistes punctatus ${ }^{2}$ & $0.4(0.5)$ & $9.4(2.8)$ & $3(2.0)$ & - & $0.4(0.5)$ & - \\
\hline Liopetrolisthes mitra ${ }^{2}$ & - & $1.6(1.1)$ & $0.4(0.5)$ & - & - & - \\
\hline Petrolisthes violaceus ${ }^{2}$ & $0.5(0.6)$ & $10.6(1.1)$ & $5.0(2.0)$ & - & - & - \\
\hline Petrolisthes granosus ${ }^{2}$ & $1.8(2.5)$ & $9.2(1.8)$ & $1.4(1.3)$ & - & - & - \\
\hline Petrolisthes tuberculatus ${ }^{2}$ & $0.4(0.5)$ & $7.2(1.3)$ & $3(1.4)$ & - & - & - \\
\hline \multicolumn{7}{|l|}{ Insecta } \\
\hline Diptera adults 3 & $6.26(6.1)$ & $2.4(1.8)$ & - & $5.0(5.3)$ & $10.3(4.3)$ & - \\
\hline \multicolumn{7}{|l|}{ Echinodermata } \\
\hline Stichaster striatus ${ }^{1}$ & - & - & - & - & - & $1.2(1.4)$ \\
\hline Heliaster helianthus ${ }^{1}$ & - & - & - & $0.2(0.5)$ & $1.0(1.3)$ & $0.2(0.4)$ \\
\hline
\end{tabular}




\section{Dietary and intertidal species composition}

Dietary composition of C. nigrofumosus (Table 1) mirrored abundances of marine prey recorded at both sites (Table 2). In particular, prey with the highest abundances at high and mid intertidal zones showed the highest dietary representations (FO and \% weight) at El Quisco (Allopetrolistes punctatus and Amphipoda-Gamaridae) and Taltal (Nodilittorina peruviana, Amphipoda-Gamaridae, Leptograpsus variegatus and Grapsus grapsus). On the other hand, there was no relation between the abundance of insects (adults of Diptera) in the field (higher in Taltal, Table 2) and their incidence on the diet of Cinclodes (higher in El Quisco, Table 1).

\section{DISCUSSION}

A few passerines exploit marine habitats and present adaptations to cope with high salt loads such as drinking fresh water, feeding on less saline food, and/or increasing kidney volume and efficiency. Based on the broad geographical range of $C$. nigrofumosus on the Chilean coast, and in concordance with differences in fresh water availability, we predicted that birds from more arid regions would exhibit higher osmotic loads and include (when available) more terrestrial prey on their diet to reduce stomach osmolality than birds of more mesic sites. Our study revealed that C. nigrofumosus from El Quisco (mesic site) and Taltal (arid site) have similar dietary preferences. Overall, these birds forage at mid and low intertidal levels, consuming marine prey in direct relation with their environmental availability.

Although the incidence of crustacean and insects in the diet of C. nigrofumosus did not differ between populations (more than $80 \%$ of crustaceans), osmolality of stomach contents at the El Quisco population was lower than at Taltal. These birds ingested primarily osmoconforming invertebrates, but osmolality of their stomach contents remained lower than that of seawater. Although osmolality of dietary fluids may have decreased because food in the stomach is mixed with gastrointestinal secretions (Chang \& Rao 1994, Denbow 2000), our measures were good estimators of the osmotic load. Two reasons support this idea. First, osmolality of stomach content in Cinclodes species is positively correlated with urine osmolality in the field (Sabat \& Martínez del Río 2002), and urine osmolality is a good estimator of osmotic load in birds (Goldstein \& Braun 1989, Goldstein \& Zahedi 1990). Second, when samples are collected just after feeding trials, as in our study, the stomach content osmolality is similar to that of prey consumed by birds (Mahoney \& Jehl 1985, Janes 1997). Hence, we are confident in that osmolality of stomach contents provides a good relative estimate of ingested osmotic loads. However, dilution by gastrointestinal secretions probably render it a poor estimate of absolute osmotic load.

The relationship between stomach prey content and osmolality could be affected by consumption of freshwater. At El Quisco C. nigrofumosus presumably have more access to fresh water and their stomach content exhibited a lower osmolality than expected for a diet composed mainly by marine prey. Indeed, birds from El Quisco occasionally drink (P. Sabat unpublished results) in temporary pounds containing a mix of seawater and human-settlement discharges (with osmolalities as lower as $50 \mathrm{mOsm} \mathrm{kg}^{-1}$ ). However, where presumably no fresh or dilute water is available, as in the coastal desert site of Taltal, these birds had a higher stomach content osmolality, and osmolality in some individuals reached values as high as $1,200 \mathrm{mOsm} \mathrm{kg}^{-1}$. This might explain why there was no relationship between diet composition and osmolality. Our results support the hypothesis that $C$. nigrofumosus from El Quisco reduce their osmotic load by means of drinking fresh water.

Several birds use prey selection to diminish osmotic load when feeding in saline habitats (Johnston \& Bildstein 1990). Madsen (1954) documented that the long-tailed duck (Clangula hyemalis) included $47 \%$ of bivalves (which have high content of salt in relation to other prey) in their diet when feeding in sites of moderate salinity, but took near to $65 \%$ of such prey when feeding in low-salinity sites. Ionic concentration of stomach contents can be diluted by drinking freshwater and through the ingestion of prey items with low osmolality. The ability to choose less salty prey (insects) and/or drinking dilute water to decrease the osmotic load, may explain the success of these birds to exploit such a prey-rich environment. Alternatively, physiological features, as higher plasma osmolality and urine concentration (Sabat \& Martínez del Río 2002), are an additional response to high osmotic loads imposed by a diet comprised mainly of marine invertebrates.

Diet of birds are influenced by individual preferences, physiological limits and environmental availability. Most maritime prey consumed by $C$. nigrofumosus (mollusks and crustaceans) are osmoconformers (Gilles 1987) and hence saltloaded. Theoretically, the proportion of maritime prey might be correlated with the stomach con- 
tent osmolality. However, the stomach content osmolality of marine populations of Cinclodes that forage on marine invertebrates at intertidal zones is typically lower than the concentration expected for a marine prey-eater. Only two individuals of $C$. nigrofumosus from Taltal had a stomach content osmolality comparable to seawater. The stomach content of birds from El Quisco had a lower osmolality than seawater. Such differences between stomach content and seawater strongly suggest that these birds are capable of selecting prey with lower osmolality and/or to drink more dilute water. This may explain why, in spite of the differences on the availability of Diptera (higher at Taltal than at El Quisco), individuals from both sites consume similar amounts of insects (10\% of their dietary composition), probably as a way of diluting the high salt content of marine prey.

Several studies have shown that salt-marsh passerines are not able to tolerate drinking full strength seawater (Poulson 1969, Basham \& Mewaldt 1987). Cinclodes species, especially $C$. nigrofumosus are able to tolerate osmoconforming invertebrates, but their ability to tolerate seawater remains unknown. It may be well that specific solute composition of prey is important. Invertebrate fluids likely contain high amounts of potassium amino acids compared to the high $\mathrm{NaCl}$ concentration of seawater and experimental drinking waters (Schmidt-Nielsen 1997). Eating these osmoconforming invertebrates, particularly if accomplished without a high intake of seawater, may be less stressful. In spite of these considerations, the fact that no passerine species other than Cinclodes takes advantage of the abundant food supply at intertidal zones is, to some extent, related to their particular physiological and behavioral abilities to get rid of salt loads.

Cinclodes nigrofumosus seem well suited to exploiting marine environments in a variety of ways. First, they can respond behaviorally by choosing prey with low salt contents (e.g., insects). Second, the birds can drink fresh or less salty water occasionally to decrease the high salt concentration of marine prey, as in El Quisco. Moreover, these birds probably have the ability to excrete high proportion of electrolytes as suggested by their field urine osmolality and by their renal morphology (i.e., similar to the one of other passerines that inhabits salt marshes, Goldstein Williams \& Braun 1990, Casotti \& Braun 2000, Sabat \& Martínez del Río 2002). We predict that their ability to concentrate urine will be higher in C. nigrofumosus than in other passerines, including other members of the genus. If so, it could explain why these birds can live in a desert coast where fresh water is presumably not available, eat high salinity prey, and handle the high salt load. On the contrary, other members of the genus (e.g., C. patagonicus and C. oustaleti) could be less effective at handling marine prey, and their dietary preferences and habitat use may be constrained by their osmoregulatory physiology (Sabat \& Martínez del Río 2002). These differences in the osmoregulatory features observed among Cinclodes species may partially explain why no other Cinclodes species occurs in arid sites, even though other species occur at same latitudes but only in Andean streams. Similarly, such differences also may account for the seasonal migration of $C$. oustaleti from coastal to stream habitats during hot and dry summers in mesic regions, when the availability of fresh water decreases (December to March, Sielfeld et al. 1996, Jorge et al. 1998). Further studies are needed to elucidate how seasonal differences in precipitation and temperature on the one end, and physiological limits on the other, determine diet breadth, dietary selection, and influence migratory behavior of maritime Cinclodes species.

\section{ACKNOWLEDGEMENTS}

Thank to Julie Ellis, José Miguel Rojas and Antonio Rivera for their comments, field assistance and support. We are grateful to tree anonymous referees for helpful coments during the preparation of the manuscript. This study was supported by FONDECYT grant 1010647 to PS. At the time of this study, J.M. Fariña was a post-doctoral researcher at Brown University under a Mellon Grant to Mark Bertness and Jon Witman.

\section{LITERATURE CITED}

ARAYA B, GM MILLIE \& M BERNAL (1986) Guía de campo de las aves de Chile. Editorial Universitaria, Santiago, Chile. 405 pp.

BASHAM MP \& LR MEWALDT (1987). Salt water tolerance and the distribution of south San Francisco bay song sparrows. Condor 89: 697-709.

BRAUN EJ (1981) Renal function. Comparative Biochemistry and Physiology 71A: 511-517.

CASOTTI G \& EJ BRAUN (2000) Renal anatomy in sparrows from different environments. Journal of Morphology 243: 283-291.

CASTILLA JC (1988) Earthquake-caused coastal uplift and it effects on rocky intertidal kelp communities. Science 242: 440-443.

CHANG EB \& MC RAO (1994) Intestinal water and electrolyte transport. In: Johnson LR (ed) Physiology of the gastrointestinal tract: 2027-2081. Raven Press, New York, New York, USA. 
DANTZLER WH \& EJ BRAUN (1980) Comparative nephron function in reptiles, birds and mammals. American Journal of Physiology 239: R197-R213.

DENBOW DM (2000) Gastrointestinal anatomy and physiology. In: Whittow GC (ed) Sturkie's avian physiology: 299-326. Academic Press, London, United Kingdom.

DI CASTRI F \& E HAJEK (1976) Bioclimatología de Chile. Editorial de la Universidad Católica de Chile, Santiago, Chile. 129 pp.

GILLES R (1987) Volume regulation in cells of euryhaline invertebrates. Current Topics in Membranes and Transport 30: 205-247.

GOLDSTEIN DL \& EJ BRAUN (1989) Structure and concentrating ability in the avian kidney. American Journal of Physiology 25: R501-R509.

GOLDSTEIN DL \& A ZAHEDI (1990) Variation in osmoregulatory parameters of captive and wild house sparrows (Passer domesticus). Auk 107: 533-538

GOLDSTEIN DL, JB WILLIAMS \& EJ BRAUN (1990) Osmoregulation in the field by salt-marsh Savannah sparrows Passerculus sandwichensis beldingi. Physiological Zoology 63: 669-682.

GOLDSTEIN DL \& E SKADHAUGE (2000) Regulation of body fluid composition. In: Whittow GC (ed) Sturkie's avian physiology: 265-297. Academic Press, London, United Kingdom.

GOODALL J, AW JOHNSON \& RA PHILIPPI (1946) Las aves de Chile, Volumen 1. Platt Establecimientos Gráficos, Buenos Aires, Argentina. 439 pp.

HOUSSE R (1945) Las aves de Chile en su clasificación moderna. Ediciones de la Universidad de Chile, Santiago, Chile. 390 pp.

HOCKEY PAR, AL BOSMAN \& PG RYAN (1987) The maintenance of polymorphism and cryptic Mimesis in the Limpet Scurria variabilis by two species of Cinclodes (Aves: Furnaridae) in central Chile. Veliger 30: 5-10.

HOLMES W N \& JG PHILLIPS (1985) The avian salt gland. Biological Reviews 60: 213-256.

JANES DN (1997) Osmoregulation by Adelie pinguin chicks on the Anctartica peninsula. Auk 114: 488495.

JOHNSTON JW \& KL BILDSTEIN (1990) Dietary salt as a physiological constraint in white Ibis breeding in a estuary. Physiological Zoology 63: 190-207.

JORGE R, E TABILO-VALDIVIESO \& V MONDACA (1998) Avifauna de la bahía de Coquimbo, Chile. Boletín Chileno de Ornitología (Chile) 5: 2-9
LIETH H (1978) Primary productivity in ecosystems: comparative analysis of global patterns. In: Lieth $\mathrm{H}$ (ed) Patterns of primary productivity in the biosphere: 301-321. Hutchinson \& Ross, Stroudsburg, Pennsylvania, USA.

MADSEN FJ (1954) On the foods habits of the diving ducks in Dennmark. Danish Review of Game Biology 2: 157-266.

MAHONEY SA \& JR JHEL Jr (1985) Physiological ecology and salt loading of California gulls at an alkaline, hypersaline lake. Physiological Zoology 58: 553-563.

NYSTRÖM KGK \& O PEHRSSON (1988) Salinity as a constraint affecting food and habitat choice of mussel-feeding diving ducks. Ibis 130: 94-110.

PAYNTER RA Jr (1971) Nasal glands in Cinclodes nigrofumosus, a maritime passerine. Bulletin of the British Ornithological Club 91: 11-12.

POULSON TL \& GA BARTHOLOMEW (1962) Salt balance in the savannah sparrow. Physiological Zoology 35: 109-119.

POULSON TL (1969) Salt water tolerance in seaside and sharp-tailed sparrows. Auk 86: 473-489.

PURDUE JR \& H HAINES (1977) Salt water tolerance and water turnover in the snowy plover. Auk 94: 248-255.

SABAT P \& C MARTÍNEZ DEL RÍO (2002) Inter- and intraspecific variation in the use of marine food resources by three Cinclodes (Furnariidae, Aves) species: carbon isotopes and osmoregulatory physiology. Zoology 105: 247-256.

SHOEMAKER V (1972) Osmoregulation and excretion in birds. In: Farner DS, J King \& K PARKES (eds) Avian biology: 527-612. Academic Press, London, United Kingdom.

SCHMIDT-NIELSEN K (1997) Animal physiology, adaptation and environment. Cambridge University Press, New York, New York, USA. 612 pp.

SIEGEL S \& NJ CASTELLAN (1988) Nonparametric statistics for the behavioral sciences. McGraw-Hill, New York, New York, USA. 399 pp.

SIELFELD W, N AMADO, J HERREROS, R PEREDO \& A REBOLLEDO (1996) La avifauna del salar de Huasco: Primera Región, Chile. Boletín Chileno de Ornitología (Chile) 3: 17-24.

SIMON E (1982) The osmoregulatory system of birds with salt glands. Comparative Biochemistry and Physiology 71: 547-556.

WILKINSON L, G BLANK \& C GRUBER (1996) Desktop data analysis with SYSTAT. Prentice-Hall, Upper Saddle River, New Jersey, USA. 798 pp. 